\title{
SUPPRESSION OF ADJUVANT ARTHRITIS BY A NEW CYTOTOXIC COMPOUND, RUBIDOMYCIN
}

\author{
BY \\ F. QUAGLIATA,* PHILIPPA M. SANDERS, $\uparrow$ AND D. L. GARDNER $\ddagger$ \\ Division of Experimental Pathology, Kennedy Institute, London.
}

A vigorous search continues for drugs capable of alleviating those connective tissue diseases which are mediated by immunological mechanisms. The experimental disorder caused in rats by the injection of Freund's complete adjuvant or of mycobacteria suspended in oil has been used extensively to test compounds for this purpose. Adjuvant disease, of which polyarthritis is a prominent feature, is highly reproducible and is believed to be the result of a delayed hypersensitivity reaction against antigen(s) associated with the peptide-glyco-lipides of the wax D fraction of the mycobacteria or of the nocardia (Bonhomme, 1967; Pearson, Wood, and Tanaka, 1968). This paper reports a study of adjuvant disease under treatment with the new cytotoxic drug, Rubidomycin.

Rubidomycin (Fig. 1), an anthracycline derivative with antibiotic properties (Dubost, Ganter, Maral, Ninet, Pinnert, Preud'homme, and Werner, 1963), is known to possess cytotoxic activity both in vitro

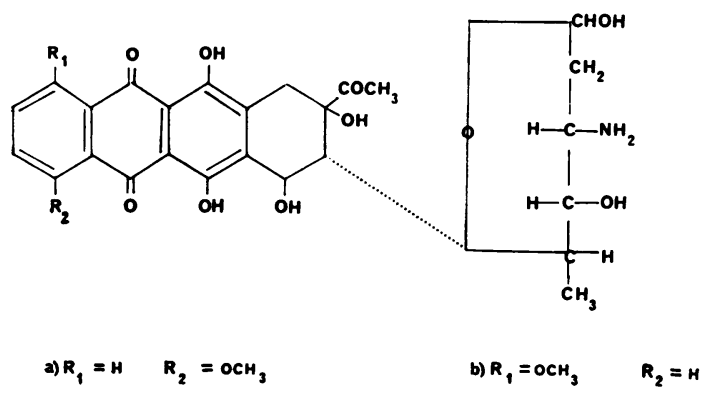

Fig. 1.-Simplified formula for Rubidomycin. The manner in which the two components of the molecule are linked is not yet certain.

\footnotetext{
*Work conducted during the tenure of a Nuffield Research Fellow"Work conducted during the tenure of a Nuffield Research Fellow-
ship. Present address: Department of Medicine, New York Univership. Present address: Department of
sity Medical Center, New York 10016 .

†Junior Research Fellow, Medical Research Council.

$\ddagger$ Director, Kenneds Institute.
}

and in vivo against resting and dividing cells. In affected cells it causes modification of the nuclear chromatin and reduction in nucleolar size, a decrease in mitotic activity and chromosome breaks ( $\mathrm{Di}$ Marco, Soldati, Fioretti, and Dasdia, 1963; Magluilo, Strassano, and Fiori, 1964; Costa and Astaldi, 1964). The drug has been used in man for the treatment of leukaemia and other neoplastic diseases (Tan, Tasaka, and Di Marco, 1965; Tan and Tasaka, 1966; Tan, Tasaka, Yu, Murphy, and Karnofsky, 1967). Because of these properties it was considered that the activity of Rubidomycin in rat adjuvant arthritis should be examined. The results of a first, preliminary study have been reported briefly elsewhere (Quagliata, Sanders, and Gardner, 1968a).

\section{Material and Methods}

54 male albino inbred Wistar rats were caged in random groups of three and maintained on a standard pellet ration.

An adjuvant mixture was used which contained $50 \mathrm{mg}$. steam-killed, dried Mycobacterium tuberculosis of the human strains PN, DT, and C, finely ground in $10 \mathrm{ml}$. sterile liquid paraffin.

Caliper measurements of the thickness of the paws were made to the nearest $0.5 \mathrm{~mm}$.

Visual assessments of the reaction in uninjected paws were recorded on a 4-point scale in which $0=$ no reaction; $+=$ a single joint inflamed $++=$ more than one joint involved; and $+++=$ widespread inflammation and ankylosis. The assessment of all uninjected paws was summed to give an arthritic score.

Uric acid levels were measured in serum samples by the method of Liddle, Seegmiller, and Laster (1959). Microimmunoelectrophoresis was performed according to the method of Scheidegger (1955). Rat sera were developed against rabbit anti-rat globulin.

For histological study, hind limbs, thymus, spleen, and regional lymph nodes were fixed in neutral formol saline. Blocks of hind limb joints were decalcified in a formic acid/sodium citrate mixture and paraffin sections were 
stained with haematoxylin and eosin. Synovitis, periarthritis, and bone disease were assessed microscopically. The spleen, thymus, and lymph nodes were examined for evidence of hypertrophy or atrophy of primary lymphoid follicles, for germinal centre formation, for focal necrosis or fibrosis, for evidence of perisplenitis, and for numbers of plasma cells and of multinucleated or multilobed giant cells. The microscopic reactions were graded on a 5-point scale which was subsequently converted to a numerical form.

Rubidomycin (Daunomycin) (May and Baker batch 104) and tetracycline (Tetracyn-Pfizer, lot 603-710-25) were dissolved in 0.9 per cent. $\mathrm{NaCl} \mathrm{w} / \mathrm{v}$ to give final concentrations of $1 \mathrm{mg} . / \mathrm{ml}$. and $10 \mathrm{mg}$. $/ \mathrm{ml}$. respectively.

\section{Procedure}

Each animal was injected intradermally with $0.05 \mathrm{ml}$. adjuvant mixture into the volar surface of the left hind paw. After injection the animals were observed closely; body weights and joint responses were measured each day, and the severity of the reaction at the site of injection of adjuvant and of the polyarthritis which developed after a latent interval of 9 to 10 days was graded by caliper measurements. Arthritic scores were recorded independently (Figs 2 and 4).

Total and differential white blood cell counts and total red cell counts were made at approximately weekly intervals. At death, blood was collected for uric acid determinations and for microimmunoelectrophoresis.

Two experiments were performed: the first was a pilot study to determine whether any effect of Rubidomycin could be observed; the second endeavoured to identify the latest time in the course of adjuvant disease at which the use of Rubidomycin could be shown to influence the arthritis.

\section{Experiment 1}

24 rats were divided randomly into groups of three: alternate groups were then given intraperitoneal injections either of Rubidomycin $1 \mathrm{mg} . / \mathrm{kg}$. or of the control antibiotic tetracycline $10 \mathrm{mg} . / \mathrm{kg}$. from the 4 th to the 9 th days after the injection of adjuvant. The treated and control animals were killed in paired groups of four at 17, at 21 , and at 25 days.

\section{Experiment 2}

30 rats were divided at random into five groups, and treated as follows.

Group I: Rubidomycin from 3 days before the injection of adjuvant (Day -3) for 28 days;

Group II: tetracycline from Day -3 to Day 47;

Group III: Rubidomycin from Day 4 after the injection of adjuvant for 28 days;

Group IV: Rubidomycin from Day 9 for 25 days;

Group V: Rubidomycin from Day 18 for 28 days.

Occasional animals died during the course of the experiment; in these instances, terminal blood counts, uric acid determinations, and microimmunoelectrophoresis could not be undertaken, but, when possible, tissues were collected for microscopy.

\section{Experiment 1}

\section{Results}

For the 25 days of the experiment the animals treated with Rubidomycin remained in better general condition and were more active physically than the control animals given tetracycline. The control rats moved with reluctance when placed on a bench; those given Rubidomycin moved freely. The loss of weight which normally follows the injection of adjuvant was halted by Rubidomycin treatment (Fig. 2). Although Rubidomycin was given for only 6 days, the suppressive effect of treatment on the secondary response to adjuvant was recognizable throughout the period of observation. The influence of treatment on the development of arthritis was readily recognized in the non-injected paws (Fig. 3) but was less easily defined in the left hind paw into which adjuvant had been injected. Thus, there was a slight mean reduction in the arthritic score for the injected paws but a significant reduction for the three non-injected paws (Fig. 2). Similarly, caliper measurements revealed a less marked increase in size in both the injected and non-injected paws in

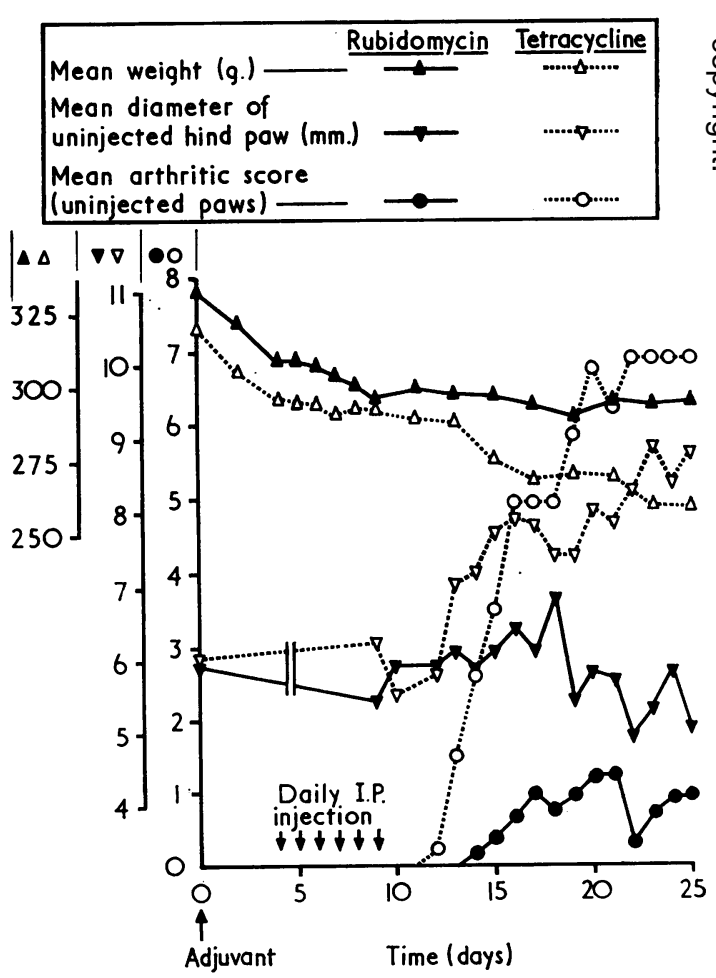

Fig. 2.-Experiment 1. Response of rat weights, paw measurements and arthritic scores for Rubidomycin- and tetracycline-treated animals. 


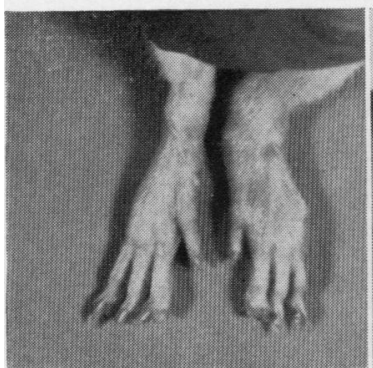

(a)

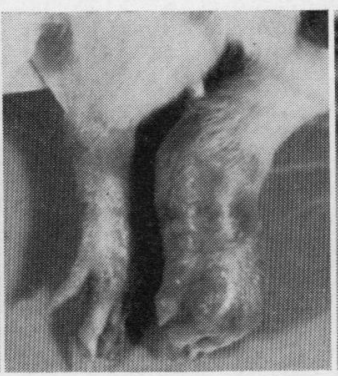

(b)

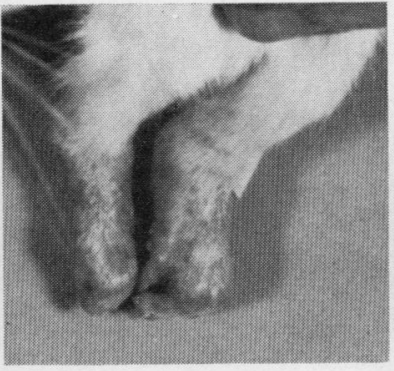

(c)

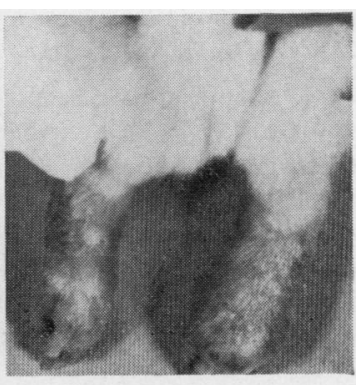

(d)

Fig. 3.-Response of hind paws to administration of tetracycline or Rubidomycin (Experiment 128): (a) Rubidomycin from Day - 3; (b) Tetracycline from Day - 3; (c) Rubidomycin from Day 9; (d) Rubidomycin from Day 18.

rats given Rubidomycin, but the difference between treated and control groups was more pronounced in the right, uninjected, paws (Fig. 2).

In both groups of animals there was a 12 per cent. reduction in red blood cell counts between Day 11 and Day 17, after which the counts in the Rubidomycin-treated animals rose steadily to regain normal levels by Day 25 . In the control tetracycline-treated animals, counts continued to decline by a further 8 per cent. White blood cell counts showed that the leucocytosis which normally accompanies the onset of adjuvant arthritis (Glenn, Gray, and Kooyers, 1965) and which was present in the tetracycline-treated animals, was not observed in the animals given Rubidomycin. However, differential white cell counts showed that, while the ratio of polymorphonuclear to mononuclear cells remained unchanged from normal for both groups, the mononuclear cells in the Rubidomycin-treated group appeared to be larger than in the tetracyclinetreated group and to have a lower nucleocytoplasmic ratio, suggesting that they were less mature forms.
Irrespective of the time of killing, the uric acid levels in animals given Rubidomycin did not differ significantly from those in the animals given tetracycline (Table I). Microimmunoelectrophoretic analysis revealed no significant qualitative difference in the pattern between the two groups of animals.

Histological observations showed that in eleven of the twelve animals given tetracycline a severe polyarthritis had developed with synovitis, pannus formation, bone destruction, new bone formation, and periarthritis. In the left hind paws, injected with adjuvant, there was in addition a characteristic persistence of lipid droplets surrounded by polymorphs and, frequently, plasmatic vasculosis.

In the rats given Rubidomycin the latter reaction, at the site of injection, was unchanged, but the synovitis, cellulitis, periarthritis, and bone destruction were greatly reduced in extent and intensity. The differences between the treated and untreated groups are best indicated by reference to the numerical grades shown in Table II. Treatment had little recognizable influence on the structure of the

TABLE I

SERUM URIC ACID LEVELS FOR THE TETRACYCLINE- AND RUBIDOMYCIN-TREATED RATS OF EXPERIMENTS 1 AND 2

\begin{tabular}{|c|c|c|c|c|c|c|c|c|}
\hline \multirow{2}{*}{$\begin{array}{l}\text { Experiment } \ldots \\
\text { Tetracycline . }\end{array}$} & \multirow{2}{*}{$\cdots$} & \multirow{2}{*}{$\cdots$} & \multirow{2}{*}{$\cdots$} & \multirow{2}{*}{$\cdots$} & \multicolumn{2}{|c|}{1} & \multicolumn{2}{|c|}{2} \\
\hline & & & & & (Days 4-9) & $4 \cdot 16 \pm 0 \cdot 69$ & (From Day -3) & $3 \cdot 14 \pm 1 \cdot 3$ \\
\hline Rubidomycin & $\cdots$ & $\ldots$ & $\ldots$ & $\ldots$ & (Days 4-9) & $3 \cdot 83 \pm 0 \cdot 77$ & $\begin{array}{l}\text { (from Day -3) } \\
\text { (from Day 4) } \\
\text { (from Day 9) } \\
\text { (from Day 18) }\end{array}$ & $\begin{array}{l}2.88 \pm 0.79 \\
3.09 \pm 0.57 \\
2.37 \pm 1.17 \\
3.05 \pm 1.64\end{array}$ \\
\hline
\end{tabular}

TABLE II

INFLUENCE OF RUBIDOMYCIN-TREATMENT FROM THE 4TH TO THE 9TH DAY AFTER THE INJECTION OF ADJUVANT ON THE HISTOLOGICAL DEVELOPMENT OF CHARACTERISTIC CELLULITIS, SYNOVITIS, AND BONE CHANGES (EXPERIMENT 1)

\begin{tabular}{|c|c|c|c|c|c|c|c|}
\hline \multirow[t]{2}{*}{ Foot } & \multirow[t]{2}{*}{$\cdots$} & \multicolumn{3}{|c|}{ Left } & \multicolumn{3}{|c|}{ Right } \\
\hline & & Cellulitis & Synovitis & $\begin{array}{c}\text { Bone } \\
\text { Destruction }\end{array}$ & Cellulitis & Synovitis & $\begin{array}{c}\text { Bone } \\
\text { Destruction }\end{array}$ \\
\hline $\begin{array}{l}\text { Tetracycline } \\
\text { Rubidomycin }\end{array}$ & 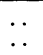 & $\begin{array}{l}4 \cdot 00 \\
3 \cdot 75\end{array}$ & $\begin{array}{l}3 \cdot 70 \\
3 \cdot 01\end{array}$ & $\begin{array}{l}3 \cdot 33 \\
2 \cdot 90\end{array}$ & $\begin{array}{l}3 \cdot 08 \\
0 \cdot 75\end{array}$ & $\begin{array}{l}2 \cdot 73 \\
0.67\end{array}$ & $\begin{array}{l}2 \cdot 20 \\
0 \cdot 16\end{array}$ \\
\hline
\end{tabular}


lymphoreticular tissues. Among the 24 animals, half showed hyperplasia of thymic medullary cells but germinal centre formation was rare. Splenic focal necrosis was identified in ten animals but was not related to whether Rubidomycin had been used in treatment. Splenic germinal centres were prominent in four animals and giant cells in six; a recognizable proliferation of perifollicular cells of plasma cell type was seen in only three rats but this change was not confined to control animals.

\section{Experiment 2}

After the prolonged administration of Rubidomycin all groups of animals, irrespective of the time of commencement of treatment with Rubidomycin, showed a continued weight loss. By contrast, the weight loss which accompanies the response to adjuvant was not maintained in the tetracyclinetreated group of control animals. These findings differ from the results of Experiment 1 in which treatment with Rubidomycin was given for only 6 days.

Red blood cell counts did not differ from those of control animals given tetracycline except in the group in which Rubidomycin treatment was begun 3 days before the injection of adjuvant. This group showed counts which remained within the limits of normality throughout the experiment. White blood cell counts for the four groups given Rubidomycin revealed a marked and consistent downward trend beginning immediately treatment was begun. As in Experiment 1, differential white cell counts showed no change in the ratio of polymorphs to mononuclear cells but the latter again displayed an increased proportion of immature forms.

Microimmunoelectrophoretic analyses of the sera developed against rabbit anti-rat globulin revealed no qualitative change in treated animals which was not present in control sera.

No significant change in serum uric acid levels was recognized in animals treated with Rubidomycin by comparison with tetracycline-treated controls.

Suppression of the development of adjuvant disease by treatment with Rubidomycin was again confirmed in this second experiment. Rubidomycin given on or before the 4th day after injection of adjuvant suppressed the development of adjuvant arthritis (Fig. 4) in both the injected and uninjected paws as observed by direct measurement with calipers or as expressed in the arthritic score. Treatment with Rubidomycin from Day 9 did not suppress the appearance of the secondary lesions but had some effect on their severity, whereas treatment commencing on Day 18 after the injection of adjuvant had no effect on the development of the disease (Fig. 4).

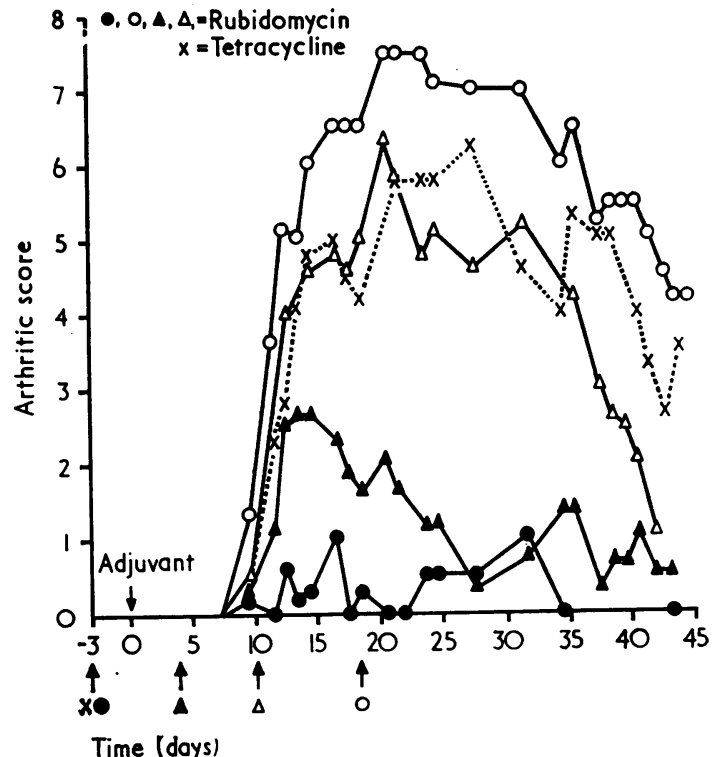

Fig. 4.-Experiment 2. Response of Rubidomycin- and tetracyclinetreated animals, expressed as arthritic score.

In none of the Rubidomycin-treated animals did the serum uric acid levels differ significantly from those in rats treated with tetracycline (Table I).

Histological study showed that, as in the first experiment, treatment with Rubidomycin from Day 10 or from Day 18 exerted little influence on the development of the tissue reactions which accompanied the injection of adjuvant into the left foot. However, the response at the injection site was slightly diminished when Rubidomycin was given from Day 4 and greatly reduced when the drug was begun before adjuvant was injected. When the uninjected right foot was examined, similar responses were recognized. The extent of the residual histological reaction at the time of death did not always precisely reflect the extent of the arthritis measured throughout the course of the experiment and, in occasional animals, joints which had displayed marked inflammatory reactions during life appeared structurally normal at the close of the experiment.

Microscopic study of the spleen failed to reveal any major disturbance in lymphoreticular tissue which was not also present in animals treated with the control drug tetracycline. There was, however, a suggestion that the prominence of primary lymphoid follicles and the frequency and size of secondary germinal centres was less in animals which remained untreated with Rubidomycin for 4,10 , or 18 days than in those animals to which the drug had been given from 3 days before adjuvant was injected. The numbers of animals in which 
adequate specimens of lymph nodes and of thymus were available was small. No microscopic evidence was obtained to show that treatment with Rubidomycin which was effective in suppressing arthritis had significantly changed the architecture or cytology of either of these lymphoreticular tissues.

\section{Discussion}

The present results show that Rubidomycin given early in the development of adjuvant disease suppresses the customary polyarthritis and diminishes the leucocytosis. The degree of these actions varies inversely with delay in starting treatment: animals given Rubidomycin, from 3 days before adjuvant is injected to 4 days after, display little subsequent response; those in which treatment is delayed to the 9th day show partial suppression; those given Rubidomycin from the 18th day show none.

The polyarthritis of adjuvant disease starts as an acute synovitis; periarthritis, tendinitis, and bursitis develop and the oedematous synovial tissue is infiltrated with polymorphs and mononuclear cells

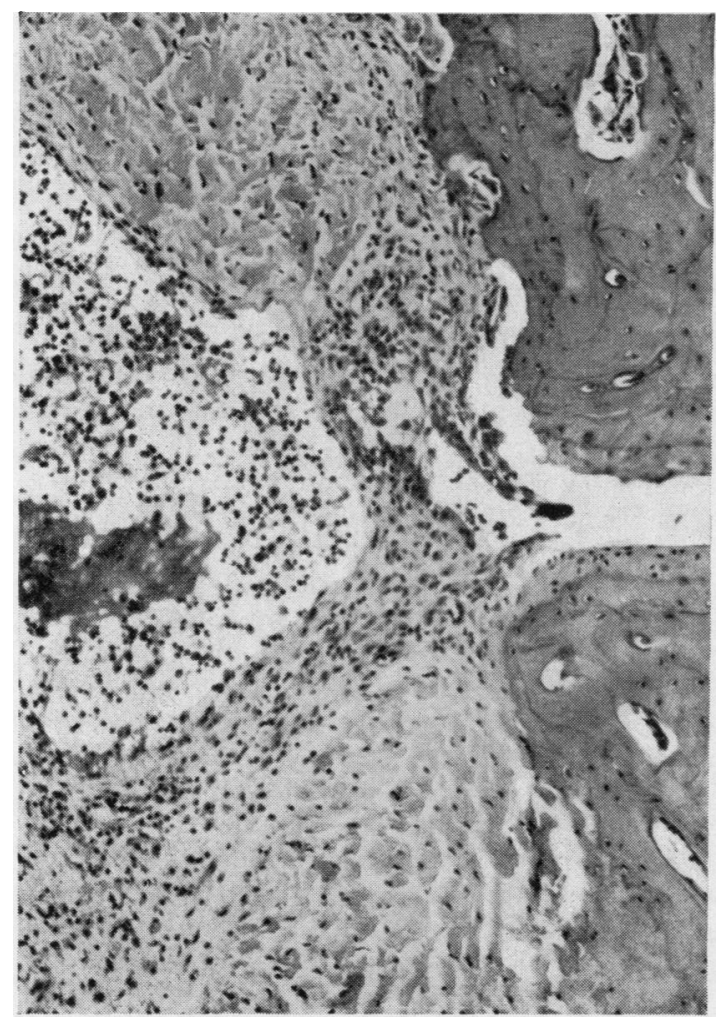

Fig. 5.-Adjuvant arthritis. Brisk synovitis with numerous macrophages and an island of fibrin (left) present within the perisynovial tissue. Haematoxylin and eosin. $\times 100$.
(Figs 5 to 8). In the untreated disease, in which there is progressive weight loss, the haemoglobin decreases (Glenn and others, 1965) and there is a polymorph leucocytosis (Lukens, Cartwright, and Wintrobe, 1967). The erthrocyte sedimentation rate is raised and there are changes in the plasma globulin levels. It is generally accepted that this arthritis and indeed the syndrome of adjuvant disease are immunological reactions against an antigenic component of a mycobacterial wax $D$ fraction. The evidence for this view is seven-fold:

(1) A latent period of approximately 2 weeks intervenes between the local intradermal injection of adjuvant and the onset of systemic disease (Pearson and Wood, 1959);

(2) The disease can be transferred to syngeneic recipients by lymphoid cell suspensions but not by serum (Waksman and Wennersten, 1963);

(3) The disease can be reproduced in "germfree" animals but not in young immunologically tolerant recipients (Pearson and Wood, 1959);

(4) The onset of adjuvant polyarthritis can be

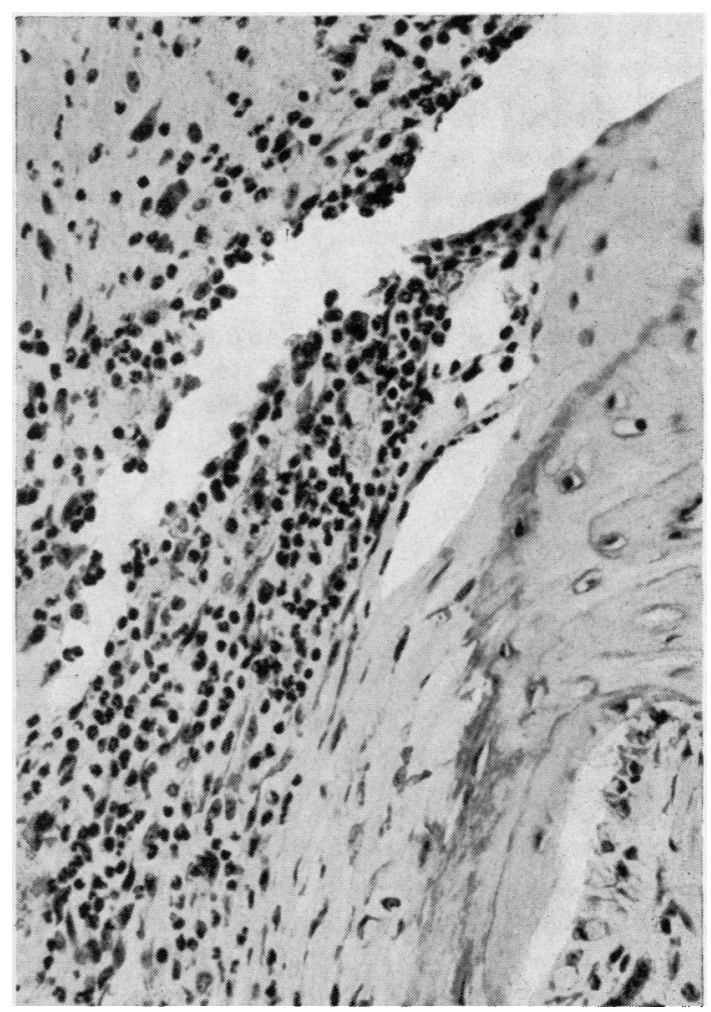

Fig. 6.-Adjuvant arthritis. Numerous polymorphs, macrophages, and occasional fibroblasts can be seen beneath the synovial cells
lining the joint surface (centre). Haematoxylin and eosin $\times 250$. 


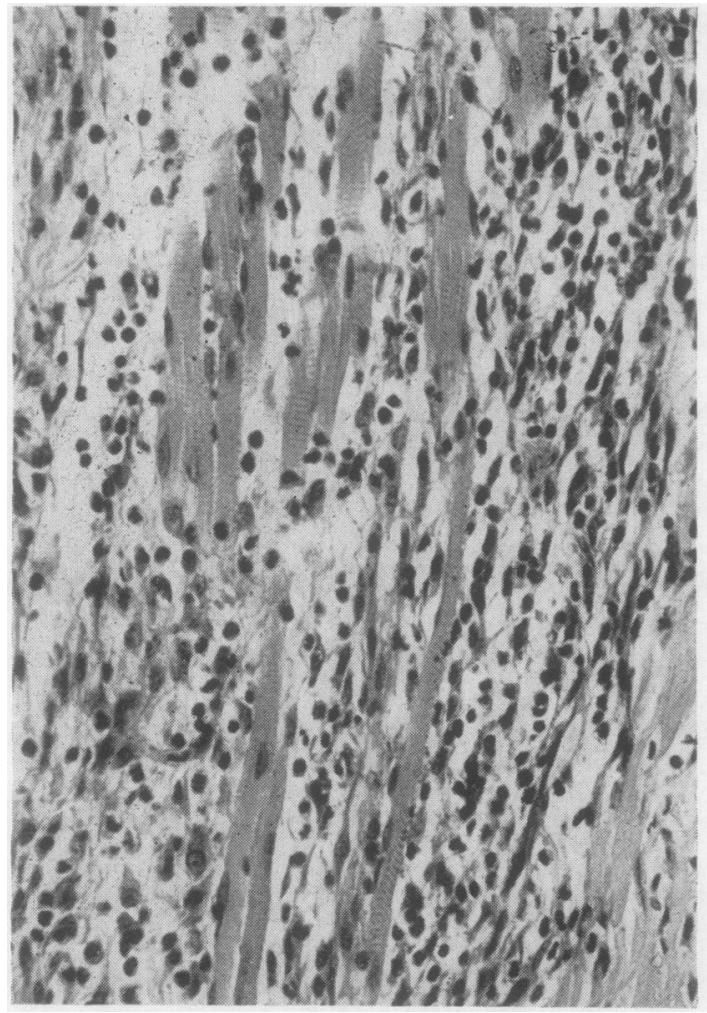

Fig. 7.-Adjuvant arthritis. A periarticular myositis is one feature of the intense inflammatory reaction surrounding the joint. Muscle cells are dispersed and interrupted by an inflammatory mononuclear cell exudate. Haematoxylin and eosin. $\times 250$.

suppressed by non-lethal whole body irradiation, by corticosteroids, by other immunosuppressive drugs, and by anti-lymphocyte serum (Table I);

(5) The treatment of rats with repeated doses of tubercle bacilli in saline reduces the response to the subsequent injection of adjuvant (Gery and Waksman, 1967);

(6) There are changes in serum protein patterns which may indicate altered immunoglobulin synthesis (Lowe, 1964);

(7) Re-injection with adjuvant is believed to be followed by a recurrence of arthritis after an abbreviated latent period (Pearson and Wood, 1959).

Many other agents of possible therapeutic value in the control of human connective tissue diseases have now been tested by administration to rats with adjuvant arthritis (Table III). Special interest attaches to those which suppress adjuvant arthritis while depressing the mechanisms of cellular immunity which are believed to mediate delayed hypersensitivity. The effective agents include wholebody irradiation, antilymphocytic serum, and radiomimetic and cytotoxic drugs (Quagliata,

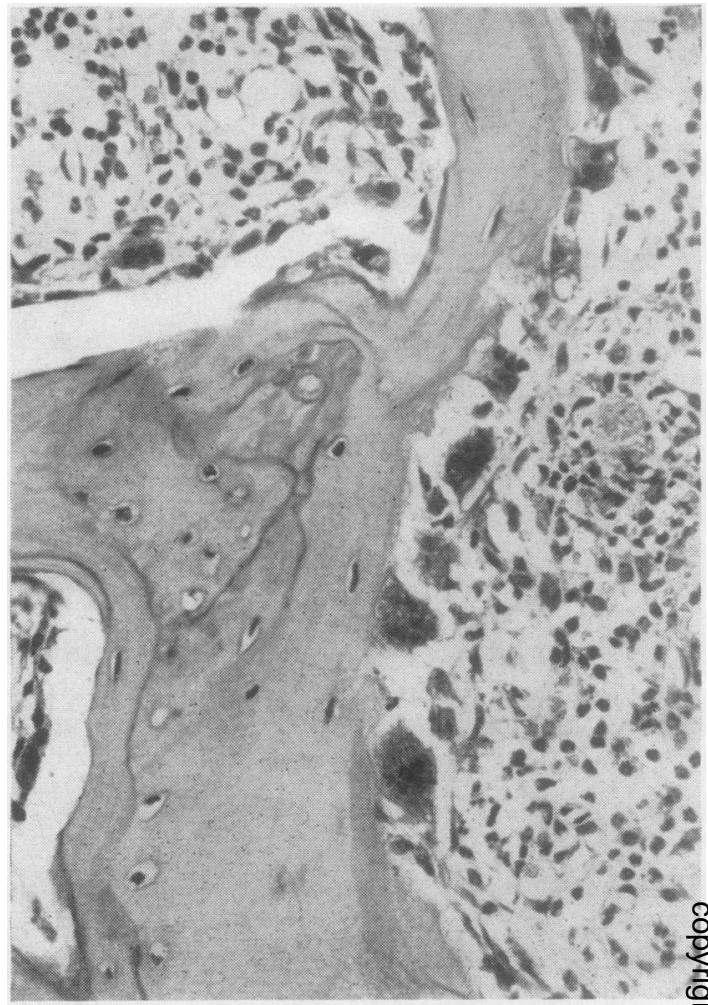

Fig. 8.-Adjuvant arthritis. Bone adjoining the articular surface of an affected joint is undergoing active osteoclastic reabsorption. Haematoxylin and eosin. $\times 250$.

Sanders, and Gardner, 1968b, c). Non-lethal, whole-body $x$-irradiation has been shown to destroy the capacity of the lymphoreticular system to respond to the antigenic material conveyed initially to regional lymphoid tissue. The effect is probably not dependent upon an action on the thymus since adjuvant disease can be caused in thymectomized rats (Jones and Ward, 1966) and the thymus, which decreases in size, shows little histological change during the development of adjuvant disease. As a corollary to these observations, it has been shown that thoracic duct lymphocyte depletion on Days 9, 10, and 11 depresses the joint manifestations of the disease (Whitehouse and Whitehouse, 1968; Quagliata, Sanders, and Gardner, 1968d). Hydrocortisone acetate and its congeners have been shown to inhibit adjuvant-induced hyperplasia of the iliac, inguinal, and axillary lymph nodes, but the effects of hydrocortisone are not specific since lymph node enlargement after the injection of Salmonella enteritidis is also inhibited (Glenn, 1966). Phenylbutazone, acetylsalicylic acid, flufenamic acid, and indomethacin, despite their 
TABLE III

AGENTS PREVIOUSLY USED IN ATTEMPTS TO SUPPRESS OR PREVENT ADJUVANT DISEASE

\begin{tabular}{|c|c|c|c|c|c|}
\hline \multicolumn{4}{|c|}{ Authors } & \multirow{2}{*}{$\frac{\text { Date }}{(1959)}$} & Drugs \\
\hline Pearson and Wood & . & $\cdots$ & $\cdots$ & & $\begin{array}{l}\text { (Penicillin), (Streptomycin), (Tetracycline), Hydrocortisone, } \\
\text { Whole-body irradiation }\end{array}$ \\
\hline \multicolumn{4}{|l|}{ Newbould } & (1963) & Steroids, Salicylates, Phenylbutazone, (Chloroquine), (Hydrochloroquine) \\
\hline \multicolumn{4}{|c|}{ Kalliomaki, Saarimaa, and Toivanen } & (1964) & 6-mercaptopurine \\
\hline Mueller and Kappas & . & $\cdots$ & . & (1964) & Oestrogen \\
\hline \multicolumn{3}{|c|}{ Ward, Cloud, Krawitt, and Jones } & $\cdots$ & $(1964)$ & Methotrexate, 6-mercaptopurine, (Mechlorethamine hydrochloride) \\
\hline Newbould & . & $\cdots$ & . & $(1965)$ & 2-butoxycarbonylmethylene-4-oxothiazolidine \\
\hline Winter and Nuss & . & $\cdots$ & $\cdots$ & (1966) & $\begin{array}{l}\text { Dexamethasone, Mefenamic acid, Phenylbutazone, Aspirin, Flufenamic acid, } \\
\text { Indomethacin }\end{array}$ \\
\hline Ward and Cloud & . & $\cdots$ & $\cdots$ & (1966) & Indomethacin, Prednisolone, Phenylbutazone \\
\hline Currey and Ziff & . & $\cdots$ & . & $(1966,1967,1968)$ & ALS (globulin) \\
\hline Glenn $\quad \ldots$ & $\cdots$ & $\cdots$ & $\cdots$ & (1966) & $\begin{array}{l}\text { Steroids, Indomethacin, Flufenamic acid, Phenylbutazone, Mefenamic acid, } \\
\text { Hydrocortisone acetate }\end{array}$ \\
\hline \multicolumn{2}{|c|}{ Kapusta and Mendelson } & $\ldots$ & $\cdots$ & (1967) & Statolon \\
\hline Jessop and Currey & $\cdots$ & . & $\cdots$ & (1968) & (Gold salts) \\
\hline \multicolumn{3}{|c|}{ Whitehouse and Whitehouse } & $\ldots$ & (1968) & Lymphocyte depletion \\
\hline
\end{tabular}

Brackets indicate no effect observed on the subsequent development of adjuvant arthritis.

inhibitory effects on the clinical signs of adjuvant arthritis, do not inhibit the increase in lymph node weight and must therefore exert inhibitory effects distinct from those of the antiinflammatory steroids.

Rubidomycin was discovered in France in 1963 (Dubost and others, 1963); it was found to have antibiotic activity and only subsequently were the cytotoxic marrow-depressive properties recognized. 6 weeks after this initial discovery the drug was independently isolated in Italy and given the name of Daunomycin (Grein, Spalla, Di Marco, and Canevazzi, 1963). Rubidomycin has been used in the treatment of human leukaemia (Massimo, Fossati-Guglielmoni and Fortuna, 1967; Tan and others, 1967; Mathé, Schwarzenberg, Schneider, Schlumberger, Hayat, Amiel, Cattan, and Jasmin, 1967; Malpas and Bodley Scott, 1968). Both in rats and mice (Dobost and others, 1963), Rubidomycin seems to possess a biphasic dose-dependent action on lymphoid tissues: low doses produce hyperplasia, high doses hypoplasia. The cytotoxic activity of the compound has been shown in vitro against KB cells and Ehrlich's ascites tumour cells (Di Marco and others, 1963). Clinical studies of patients with lymphoblastic and monoblastic leukaemia have demonstrated prolongation of survival with improvement in the general condition during F treatment. Tested in normal subjects in whom a delayed hypersensitivity reaction to tuberculin had been produced, the drug has been shown to suppress the normal response in hypersensitive recipients (Kourilsky, Dupuy, Fradelizi, Jacquillat, and Bernard, 1967).

The nature of adjuvant disease and the known properties of Rubidomycin make it likely that the action of the drug in this syndrome is upon the cells of the lymphoreticular system. However, Rubidomycin is an antibiotic with a weak growth-inhibiting action against Gram-positive organisms and coliform bacilli. The possibility must therefore at least be considered that the effect of Rubidomycin in adjuvant disease is due to antibiotic and not to immunosuppressive activity. Against this view is the evidence that other broad-spectrum antibiotics such as tetracycline appear to have no effect on the syndrome. Nevertheless, the opinion is still maintained that adjuvant arthritis may be the result of a recrudescence of a latent infection. In this case, the antibiotic properties of Rubidomycin might account for the activity observed in the present investigations, a view which could account for the comparatively trivial influence of the drug on the lymphoreticular tissues of the animals examined in the present investigation. 


\section{Summary}

Rubidomycin, an anthracycline antibiotic with cytotoxic properties, has been shown to suppress adjuvant arthritis in rats and to alleviate the systemic signs of adjuvant disease. Suppression is virtually complete when Rubidomycin is begun before or shortly after the injection of adjuvant but becomes progressively less effective when treatment is delayed. Although the normal polymorphonuclear leucocytosis which accompanies adjuvant disease is prevented by Rubidomycin, the lymphoreticular tissues of effectively treated animals show no significant evidence of depression or atrophy.

We are grateful to May and Baker Ltd. for supplies of Rubidomycin and wish to thank Miss Hannelore Kroemer and Mr. G. L. Munroe for valuable technical assistance. The laboratory is supported by the Arthritis and Rheumatism Council for Research.

\section{REFERENCES}

Bonhomme, F. (1967). Sem. Hôp. Paris, 43, 1134 (Determination du pouvoir arthrogénie chez le rat d'une fraction peptido-glyco-lipidique de cire $D$ administrée sous forme d'adjuvant du type Freund).

Costa, G., and Astaldi, G. (1964). Tumori, 50,477 (Effect of daunomycin on the proliferative activity of stem-cells developed from human leucocytes) [In Italian].

Currey, H. L. F., and Ziff, M. (1966). Lancet, 2, 889 (Suppression of experimentally-induced polyarthritis in the rat by heterologous anti-lymphocyte serum).

- (1967). Fed. Proc., 26, 418 (Abst. 905). (Immunosuppressive action of heterologous anti-lymphocyte globulin in the rat).

(1968). J. exp. Med., 127, 185. (Suppression of adjuvant disease in the rat by heterologous antilymphocyte globulin).

Di Marco, A., Soldati, M., Fioretti, A., and Dasdia, T. (1963). Tumori, 49, 235 (The activity of daumomycin, a new anti-tumour antibiotic, on normal and tumour cells growing in vitro) [In Italian].

Dubost, M., Ganter, P., Maral, R., Ninet, L., Pinnert, S., Preud'homme, J., and Werner, G. H. (1963). C. R. Acad. Sci. (Paris), 257, 1813 (Un nouvel antibiotique à propriétés cytostatiques: la rubidomycine).

Gery, I., and Waksman, B. H. (1967). Int. Arch. Allergy, 31, 57 (Studies of the mechanism whereby adjuvant disease is suppressed in rats pretreated with mycobacteria).

Glenn, E. M. (1966). Amer. J. vet. Res., 27, 339 (Adjuvant-induced arthritis: effects of certain drugs on incidence, clinical severity, and biochemical changes).

-, Gray, J.. and Kooyers, W. (1965). Ibid., 26, 1195 (Chemical changes in adjuvant-induced polyarthritis of rats).

Grein, A., Spalla, C., Di Marco, A., and Canevazzi, G. (1963). G. Microbiol., 11, 109 (Descrizione e classificazione di un attinomicete (streptomyces peucetius sp. nova) produttore di una sostanza ad attività antitumorale: la daunomicina).

Jessop, J. D., and Currey, H. L. F. (1968). Ann. rheum. Dis., 27, 577 (The influence of gold salts on adjuvant arthritis in the rat).

Jones, R. S., and Ward, J. R. (1966). "Adjuvant-induced polyarthritis in rats", in Meth. Achiev. exp. Path., 1, 607, ed. E. Bajusz and G. Jasmin. Karger, New York and Basel.

Kalliomaki, J. L., Saarimaa, H. A., and Toivanen, P. (1964). Ann. rheum. Dis., 23, 78 (Inhibition by 6-mercaptopurine of polyarthritis induced by Freund's adjuvant).

Kapusta, M. A., and Mendelson, J. (1967). Proc. Soc. exp. Biol. (N.Y.), 126, 496 (Inhibition of adjuvant arthritis by statolon).

Kourilsky, F. M., Dupuy, J.-M., Fradelizi, D., Jacquillat, C., and Bernard, J. (1967). Path. et Biol., 15, 959 (Abolition des réactions d'hypersensibilité retardée et gravité des aplasies induites par la Rubidomycine).

Liddle, L., Seegmiller, J. E., and Laster, L. (1959). J. Lab. clin. Med., 54, 903 (The enzymatic spectrophotometric method for determination of uric acid).

Lowe, J. S. (1964). Biochem. Pharmacol., 13, 633 (Serum protein changes in rats with arthritis induced by mycobacterial adjuvant).

Lukens, J. N., Cartwright, G. E., and Wintrobe, M. M. (1967). Proc. Soc. exp. Biol. (N.Y.), 126, 346 (Anemia of adjuvant-induced inflammation in rats).

Magliulo, E., Stassano, G., and Fiori, G. P. (1964). Haematologica, 49, 1091 (Antimitotic activity of daunomycin) [In Italian].

Malpas, J. S., and Bodley Scott, R. (1968). Brit. med. J., 3, 227 (Rubidomycin in acute leukaemia in adults).

Massimo, L., Fossati-Guglielmoni, A., and Fortuna, E. (1967). Arch. ital. Pat., 10, 1 (Primi risultati sull'efficacia terapeutica nella leucemia e nei tumori maligni del bambino di un nuovo antiblastico antibiotico: la "daunomicina"). 
Mathé, G., Schwarzenberg, L., Schneider, M., Schlumberger, J. R., Hayat, M., Amiel, J. L., Cattan, A., and Jasmin, C. (1967). Lancet, 2, 380 (Acute lymphoblastic leukaemia treated with a combination of prednisone, vincristine and Rubidomycin).

Mueller, M. N., and Kappas, A. (1964). Proc. Soc. exp. Biol. (N.Y.), 117, 845 (Oestrogen pharmacology. II. Suppression of experimental immune polyarthritis).

Newbould, B. B. (1963). Brit. J. Pharmacol., 21, 127 (Chemotherapy of arthritis induced in rats by mycobacterial adjuvant).

- (1965). Ibid., 24, 632 (Suppression of adjuvant-induced arthritis in rats with 2-butoxycarbonylmethylene-4-oxothiazolidine).

Pearson, C. M., and Wood, F. D. (1959). Arthr. and Rheum., 2, 440 (Studies of polyarthritis and other lesions induced in rats by injection of mycobacterial adjuvant. I. General clinical and pathologic characteristics and some modifying factors).

,-- , and Tanaka, A. (1968). Programme of Annual Meeting of Amer. Rheum. Ass., 1968 Abst. 57) (Antigenicity of mycobacterial subfractions and adjuvant-induced arthritis).

Quagliata, F., Sanders, P. M., and Gardner, D. L. (1968a). Experientia (Basel), 24, 1028 (Inhibition of rat adjuvant arthritis by a new immuno-suppressive agent-Rubidomycin).

,,,$--(1968 \mathrm{~b})$. Communication to Pathological Society of Great Britain and Northern Ireland, Bristol, July, 1968 (Abst. 22) (Suppression and transfer of adjuvant disease in rats).

,,,$---(1968 \mathrm{c})$. Communication to VII International Congress, International Academy of Pathology, Milan, September 11, 1968. (Session IX, Abst. 2). (Observations on the suppression and transfer of adjuvant disease in rats).

,,$---(1968 \mathrm{~d})$. Unpublished observations.

Scheidegger, J. J. (1955). Int. Arch. Allergy, 7, 103 (Une micro-méthode de l'immune-électrophorèse).

Tan, C., and Tasaka, H. (1966). Proc. Amer. Ass. Cancer Res., 7, 70 (Abstr. 278) (Daunomycin remissions in acute leukemia).

,-- , and Di Marco, A. (1965). Ibid., 6, 64 (Abst. 253) (Clinical studies of Daunomycin).

$\longrightarrow,-$ Y Yu, K. P., Murphy, M. L., and Karnofsky, D. A. (1967). Cancer (Philad.), 20, 333 (Daunomycin, an antitumor antibiotic, in the treatment of neoplastic disease).

Waksman, B. H., and Wennersten, C. (1963). Int. Arch. Allergy, 23, 129 (Passive transfer of adjuvant arthritis in rats with living lymphoid cells of sensitized donors).

Ward, J. R., and Cloud, R. S. (1966). J. Pharmacol. exp. Ther., 152, 116 (Comparative effect of antirheumatic drugs on adjuvant-induced polyarthritis in rats).

-, Krawitt, E. L., and Jones, R. S. (1964). Arthr. and Rheum., 7, 654 (Studies on adjuvantinduced polyarthritis in rats. III. The effect of "immunosuppressive agents" on arthritis and tuberculin hypersensitivity).

Whitehouse, M. W., and Whitehouse, D. J. (1968). Programme of Annual Meeting of Amer. Rheum. Ass., 1968 (Abst. 58) (Inhibition of rat adjuvant arthritis without drugs or antibody therapy).

Winter, C. A., and Nuss, G. W. (1966). Arthr. and Rheum., 9, 394 (Treatment of adjuvant arthritis in rats with anti-inflammatory drugs).

La suppression de l'arthrite adjuvante par un nouveau médicament cytotoxique, la rubidomycine

\section{RÉSUMÉ}

La rubidomycine, un antibiotique dérivé d'anthracycline avec des propriétés cytotoxiques a été démontrée comme pouvant supprimer l'arthrite adjuvante chez les rats et soulager les signes systémiques de la maladie adjuvante. La suppression est virtuellement complète quand la rubidomycine est donnée avant ou trés peu de temps après l'injection de l'adjuvant mais devient progressivement moins efficace quand le traitment est différé. Malgré que la leucocytose polymorphonucléaire normale qui accompagne la maladie adjuvante est empêchée par la rubidomycine, les tissus lymphoréticulaires des animaux traités efficacement ne montrent aucun signe important de dépression ou d'atrophie.
Supresión de la poliartritis adyuvante por un nuevo compuesto citotóxico: la rubidomicina

\section{SUMARIO}

Se ha demostrado que la rubidomicina, un antibiótico antraciclino con propiedades citotóxicas, suprime la poliartritis adyuvante en las ratas y alivia los signos sistémicos de la enfermedad adyuvante. La supresión es virtualmente completa cuando la rubidomicina se comienza a administrar antes o poco después de la inyección de adyuvante, pero se torna progresivamente menos eficaz cuando se retrasa el tratamiento. Si bien la leucocitosis polimorfonuclear que acompaña a la enfermedad adyuvante se previene con la rubidomicina, los tejidos linforeticulares de animales tratados eficazmente no muestran evidencia significativa de depresión o atrofia. 